\title{
Comparison of Mouth Level Exposure to 'Tar' and Nicotine in Smokers of Normal and Superslim King Size Cigarettes in Romania*
}

\author{
by \\ Madeleine Ashley, Ajit Sisodiya, Mike McEwan, John McAughey, Krishna Prasad
}

British American Tobacco, Southampton SO15 8 TL, UK

\section{SUMMARY}

Filter analysis methodology can be used to estimate smokers' mouth level exposure (MLE) to 'tar' and nicotine from spent cigarette filters. Variation in smoking behaviour and cigarette design are known to have an impact on the range of 'tar' and nicotine MLE.

Most 'King Size' (KS) cigarettes have a circumference of about $25 \mathrm{~mm}$ and are $83-84 \mathrm{~mm}$ long, with filters 20-27 mm in length. Recently, a slimmer format, described as a 'King Size Superslim' (KSSS), with a circumference of $17 \mathrm{~mm}$, has become popular in several countries. Although several studies have estimated the MLE to 'tar' and nicotine of smokers of KS cigarettes, there have been no studies of KSSS smokers reported to date.

KSSS cigarettes from Romania were chosen for this study with a single product to represent each 1,4 and $7 \mathrm{mg}$ machine-smoked ISO 'tar' yields. Since these products have filters containing activated carbon, comparisons were made with a single product at each ISO 'tar' level of KS cigarettes with both activated carbon filters (King Size Carbon - KSC), to assess the effect of format on MLE, and cellulose acetate filters (King Size Non-carbon - KSNC) to assess the effect of filter carbon on MLE. A target population of 50 to 70 male and female smokers (subjects) aged 21 to 50 years of each product were recruited in Romania, with self-reported consumption of 15-25 cigarettes per day. The subjects gave written informed consent before commencing the study.

Mean MLE to 'tar' and nicotine obtained by the smokers of all products were greater than ISO pack 'tar' and nicotine as reported in numerous studies. Regarding MLE to 'tar', there were no significant differences between the KSC, KSNC and KSSS smokers within each of the 1, 4 and $7 \mathrm{mg}$ machine-smoked ISO 'tar' yield groups, but there were significant differences between the ISO pack 'tar' groups:
$1 \mathrm{mg}<4 \mathrm{mg}<7 \mathrm{mg}$. Regarding MLE to nicotine, KSC and KSSS smokers obtained similar yields within an ISO pack 'tar' group. KSNC smokers obtained lower MLE nicotine yields than the KSC and KSSS smokers at both $4 \mathrm{mg}$ and $7 \mathrm{mg}$ ISO pack 'tar', corresponding to lower blend nicotine levels. No gender differences were observed. [Beitr. Tabakforsch. Int. 24 (2011) 277-288]

\section{ZUSAMMENFASSUNG}

Die Analyse von Zigarettenfiltern kann dazu verwendet werden, die Exposition des Mundraums von Rauchern durch Kondensat und Nikotin zu bestimmen. Unterschiedliches Rauchverhalten und das Design der Zigaretten haben erwiesenermaßen Einfluss auf die Exposition durch Kondensat und Nikotin im Mundraum. Die meisten 'King Size' (KS) Zigaretten haben einen Umfang von ca. $25 \mathrm{~mm}$, sind $83-84 \mathrm{~mm}$ lang und haben eine Filterlänge von 20-27 mm. In einigen Ländern ist eine schlankere Zigarette, die sogenannte 'King Size Superslim' (KSSS) mit einem Umfang von $17 \mathrm{~mm}$, beliebt geworden. Es gibt zwar einige Studien für KS-Zigaretten, die die Exposition durch Kondensat und Nikotin im Mundraum von Rauchern untersuchten, jedoch gibt es derzeit noch keine Studien für Raucher von KSSS-Zigaretten.

Für diese Studie wurden KSSS-Zigaretten aus Rumänien ausgewählt, die repräsentative, durch eine Rauchmaschine ermittelte ISO-Kondensatwerte von 1, 4 und $7 \mathrm{mg}$ haben. Da diese Zigaretten einen Aktivkohlefilter haben, wurden für jeden ISO-Kondensatwert zwei Vergleiche durchgeführt: mit einem KS-Produkt mit Aktivkohlefilter (King Size Carbon - KSC), um die Auswirkung des Formats auf die Exposition des Mundraums zu untersuchen, und mit einem KS-Produkt mit Celluloseacetatfilter (King Size Non-Carbon - KSNC), um die Auswirkung des Kohlefilters 
auf die Exposition des Mundraums zu untersuchen. Für jedes Produkt wurde in Rumänien eine Zielpopulation von 50 bis 70 männlichen und weiblichen Rauchern (Probanden) im Alter zwischen 21 und 50 Jahren ausgewählt, die nach eigenen Angaben 15-25 Zigaretten pro Tag rauchen.

Wie in zahlreichen anderen Studien auch war die durchschnittliche Exposition des Mundraums durch Kondensat und Nikotin aller Probanden höher als die entsprechenden nach ISO ermittelten Kondensat- und Nikotinwerte. In Bezug auf die Exposition des Mundraums durch Kondensat gab es innerhalb der Gruppen der Raucher von Zigaretten mit einem durch eine Rauchmaschine ermittelten ISO-Kondensatwert von 1, 4 oder $7 \mathrm{mg}$ keine wesentlichen Unterschiede zwischen den Rauchern von KSC, KSNC und KSSS. Große Expositionsunterschiede gab es jedoch zwischen den Probanden, die Produkte mit unterschiedlichen ISO-Kondensatwerten rauchten: $1 \mathrm{mg}<4 \mathrm{mg}<7 \mathrm{mg}$. In Bezug auf die Exposition des Mundraums durch Nikotin hatten Raucher von KSC und KSSS innerhalb der jeweiligen ISO-Kondensat-Gruppe ähnliche Expositionswerte. Raucher von KSNC hatten auf den ISO Kondensatniveaus von $4 \mathrm{mg}$ bzw. $7 \mathrm{mg}$ wegen des niedrigeren Tabaknikotins auch niedrigere Werte in Bezug auf die Exposition des Mundraums durch Nikotin als Raucher von KSC und KSSS. Es wurden keine geschlechtsspezifischen Unterschiede bezüglich Exposition durch Kondensat und Nikotin festgestellt. [Beitr. Tabakforsch. Int. 24 (2011) 277-288]

\section{RESUME}

On peut utiliser la méthode d'analyse des filtres pour estimer l'exposition au niveau de la bouche (MLE) du fumeur au goudron et à la nicotine à partir des filtres de cigarettes utilisés. Les différences en termes de comportement du fumeur et de conception des cigarettes sont réputées avoir un impact sur l'importance de la MLE au goudron et à la nicotine.

La plupart des cigarettes 'King Size' (KS) ont une circonférence d'environ $25 \mathrm{~mm}$ et mesurent $83-84 \mathrm{~mm}$ de long, dont 20 à $27 \mathrm{~mm}$ pour les filtres. Récemment, plusieurs pays ont vu se populariser un format plus fin appelé 'King Size Superslim' (KSSS), avec une circonférence de $17 \mathrm{~mm}$. Alors que plusieurs études ont déjà estimé la MLE au goudron et à la nicotine des fumeurs de cigarettes KS, aucune ne s'est jusqu'à présent intéressée aux fumeurs de KSSS.

Pour cette étude, on a choisi des cigarettes KSSS de Roumanie, avec un seul produit pour représenter chacune des teneurs en goudron ISO fumées par machine de 1, 4 et $7 \mathrm{mg}$. Etant donné que ces produits possèdent des filtres au carbone actif, on a effectué les comparaisons avec un seul produit pour chaque teneur en goudron ISO des cigarettes $\mathrm{KS}$, en utilisant des filtres au charbon actif (King Size carbone - KSC) pour évaluer l'impact du format sur la MLE et des filtres en acétate de cellulose (King Size non carbone - KSNC) pour déterminer le rôle du carbone des filtres sur la MLE. 50 à 70 fumeurs cibles (hommes et femmes) de chaque produit, âgés de 21 à 50 ans, ont été recrutés en Roumanie, ces derniers affirmant consommer 15 à 25 cigarettes par jour. Les sujets ont donné leur accord écrit en connaissance de cause avant le début de l'étude.

La MLE moyenne au goudron et à la nicotine obtenue par les fumeurs de tous les produits a été supérieure aux niveaux ISO Pack mentionnés dans de nombreuses études. Concernant la MLE au goudron, aucune différence majeure n'a été constatée entre les fumeurs de KSC, de KSNC et de KSSS dans chacun des groupes de teneur en goudron ISO fumée par machine (1, 4 et $7 \mathrm{mg}$ ), mais les différences ont été importantes entre les groupes de goudron ISO Pack : $1 \mathrm{mg}<4 \mathrm{mg}<7 \mathrm{mg}$. Concernant la MLE à la nicotine, les fumeurs de KSC et de KSSS ont obtenu des teneurs similaires au sein d'un même groupe de goudron ISO Pack. Pour les fumeurs de KSNC, la teneur en nicotine MLE a été inférieure à celle des fumeurs de KSC et de KSSS à 4 et $7 \mathrm{mg}$ de goudron ISO Pack, ce qui correspond à des niveaux de nicotine de mélange moins importants. Aucune différence homme-femme n'a été observée. [Beitr. Tabakforsch. Int. 24 (2011) 277-288]

\section{INTRODUCTION}

Smoking behaviour is known to vary widely from smoker to smoker, which means that laboratory-based methods used to measure cigarette smoke yields cannot represent the range of actual exposures in a group of smokers. Given that the amount of exposure to toxicants in cigarette smoke may relate to health risks it is important to assess the impact of cigarette design variables on the mouth level exposure to smoke yields.

Commercially available cigarettes can be found with a variety of lengths and circumferences. Typically 'King Size' (KS) cigarettes have a length of between $83 \mathrm{~mm}$ and $85 \mathrm{~mm}$ and a circumference of around $25 \mathrm{~mm}$. In a study of mouth level exposure (MLE) to 'tar' and nicotine in a US population it was found that smokers of cigarettes with a length of $100 \mathrm{~mm}$ gave slightly higher MLE than smokers of typical KS cigarettes, and smokers of cigarettes of circumferences between $23 \mathrm{~mm}$ and $17 \mathrm{~mm}$ were associated with slightly lower mouth level exposure (1).

A relatively new cigarette design format, the 'King Size Superslim' (KSSS), with a circumference of $17 \mathrm{~mm}$ and a length of $83 \mathrm{~mm}$, has become popular in some countries recently. This study seeks to evaluate whether this particular design format has any influence on MLE to 'tar' and nicotine compared with more conventional designs. The study uses subjects from Romania as this is a country where the relatively new format has become popular, and so allows a study of subjects that have been smoking such products for some time. All the KSSS cigarettes studied contained charcoal in the filter, so in comparing with more conventional KS designs we consider both cigarettes with charcoal (KSC) and without charcoal (KSNC) in their filters.

Cigarette filter-based assays have been used for many years to assess MLE to tobacco smoke constituents, and there are various methods available for such assessments (2). In this study we use a part-filter analysis method described by ST CHARLES and co-workers (3). Such an approach allows, through the analysis of spent cigarette filters, data to be collected that gives a direct estimate of smoke 'tar' and 
Table 1. Study products.

\begin{tabular}{l|cc|c|c|c|c|c}
\hline $\begin{array}{l}\text { Product } \\
\text { type }\end{array}$ & $\begin{array}{c}\text { Pack 'tar' } \\
(\mathrm{mg} / \mathrm{cig})\end{array}$ & $\begin{array}{c}\text { Pack } \\
\text { nicotine } \\
(\mathrm{mg} / \mathrm{cig})\end{array}$ & $\begin{array}{c}\text { Length } \\
(\mathrm{mm})\end{array}$ & $\begin{array}{c}\text { Circ } \\
(\mathrm{mm})\end{array}$ & Product code & Charcoal filter & $\begin{array}{c}\% \text { Tip } \\
\text { ventilation }\end{array}$ \\
\hline \multirow{3}{*}{ KSSS } & 1 & 0.2 & & 17 & KSSS 1 & Yes & 88 \\
& 4 & 0.4 & & 17 & KSSS 4 & Yes & 64 \\
KSC & 7 & 0.6 & & 17 & KSSS 7 & Yes & 33 \\
& 1 & 0.1 & & 25 & KSC 1 & Yes & 82 \\
KSNC & 4 & 0.4 & 83 & 25 & KSC 4 & Yes & 56 \\
& 7 & 0.6 & & 25 & KSC 7 & Yes & 43 \\
\hline
\end{tabular}

Circ: Circumference

nicotine yields produced by cigarettes when smoked. The methodology is unobtrusive and therefore less likely to introduce changes from normal smoking behaviour as compared to other laboratory based methods of smoking behaviour assessments. There have recently been several studies using this methodology to collect MLE data, and so it is possible to compare the values found in this current study with data from other countries with a wide range of cigarettes (4-6). Studies have also shown that MLE estimates from these filter studies correlate well with biomarkers of exposure, and hence provide a useful way to collect exposure information in large populations without the need for clinical study (7).

\section{EXPERIMENTAL}

\section{Objectives}

The objectives of the study are to use filter analysis methodology to evaluate whether cigarette circumference and charcoal in the filter have any influence on the MLE to 'tar' and nicotine obtained by smokers.

\section{Cigarettes}

To achieve the objectives of the study, the cigarette products described in Table 1 manufactured in Romania were selected for the study as follows:

- KSSS products at ISO pack 'tar' yields per cigarette (1 mg, $4 \mathrm{mg}$ and $7 \mathrm{mg}$ )

- KSC products at ISO pack 'tar' yields per cigarette (1 mg, $4 \mathrm{mg}$ and $7 \mathrm{mg}$ )

- KSNC products at ISO pack 'tar' yields per cigarette (4 $\mathrm{mg}$ and $7 \mathrm{mg}$ )

No suitable KSNC at ISO pack 'tar' yield $1 \mathrm{mg}$ was available in the Romanian market.

The cigarettes were as manufactured for commercial use and 20,000 cigarettes of each product listed in Table 1 were sourced from the same manufacturing batch. Fifteen thousand cigarettes of each product were forwarded to a market research agency (MRA), in Bucharest, Romania who conducted the study. The remaining cigarettes were sent to British American Tobacco, Group Research \&
Development, Southampton, UK (our laboratory) for physical and chemical measurements, routine and calibration smoking for the filter analysis methodology. It should be noted that the KSSS 1 and the KSC 1 products had ISO pack nicotine yields of $0.2 \mathrm{mg} / \mathrm{cig}$ and $0.1 \mathrm{mg} / \mathrm{cig}$ respectively and the KSNC 7 product had an ISO pack nicotine yield of $0.5 \mathrm{mg}$ per cigarette compared with the other $7 \mathrm{mg}$ ISO pack 'tar' products which had ISO pack nicotine of $0.6 \mathrm{mg}$ per cigarette.

\section{Subject recruitment}

An approximately equal number of healthy male and female smokers (subjects) aged between 21 and 50 with a self-reported average consumption of 15 to 25 cigarettes per day of each product were recruited. The subjects were required to have been smoking their product for at least six months and female subjects were excluded if they reported to be pregnant or lactating. The number of subjects recruited per product along with age category and gender demographics are listed in Table 2.

\section{Study protocol}

The study was conducted over a period of 11 weeks and smokers of the different products were recruited randomly over that time period.

The study comprised three visits to a test location in Bucharest and was conducted over 12 days. At visit one (day one of the study), all subjects who met with the recruiting criteria were briefed on the study protocol before giving their written informed consent to participate in the study.

Once recruited, the subjects were instructed by the MRA staff on recording their daily cigarette consumption. They were instructed to include all cigarettes smoked including those which were not their usual product. They were given a consumption diary labelled from Monday to Sunday, and instructed to record the number of cigarettes they smoked each day for seven consecutive days. Approximately one percent of the subjects also smoked at least one other product during the seven days, but as discussed by ST CHARLES et al. (3), providing only filters from the study cigarettes are collected by the subjects, study compliance is 
Table 2. Actual demographic profiles of smokers who completed study.

\begin{tabular}{lc|c|c|c|c|c|c|c|c}
\hline & \multicolumn{10}{c}{ Recruitment } \\
\hline Category & Product & KSSS 1 & KSSS 4 & KSSS 7 & KSC 1 & KSC 4 & KSC 7 & KSNC 4 & KSNC 7 \\
\hline \multirow{4}{*}{ Gender } & total & 48 & 52 & 52 & 54 & 67 & 72 & 54 & 50 \\
& male & 29 & 24 & 27 & 22 & 33 & 33 & 24 & 26 \\
& female & 19 & 28 & 25 & 32 & 34 & 39 & 30 & 24 \\
Age groupings & $21-24$ & 16 & 22 & 26 & 16 & 22 & 19 & 7 & 9 \\
& $25-29$ & 9 & 9 & 7 & 8 & 11 & 10 & 9 & 6 \\
& $30-44$ & 10 & 11 & 13 & 10 & 19 & 21 & 19 & 23 \\
\hline
\end{tabular}

unaffected if a subject uses another product.

On day nine of the study, the subjects returned to the test location for visit two with their consumption diary (completed between day two to eight of the study inclusive). They were provided with a filter cutter, cigarette filter collection instructions and a sufficient number of cigarettes of their usual brand to smoke for two days based on each subject's self reported daily cigarette consumption. Depending on the length of the mouth end section of the product and its circumference, different types of filter cutter were distributed. In this study the definition of mouth end section for dual or triple filters is the specific filter part on the mouth end and for single filters mouth end is defined as the whole filter. 10-mm filter cutters were distributed for six of the eight products and 5-mm cutters were distributed for the two KSC products where the mouth end filter section was only $7 \mathrm{~mm}$. This was to ensure the part filter would not contain carbon which interferes with the measurement of nicotine in the part filters (8). The subjects were trained how to use the filter cutter and were instructed to smoke the supplied cigarettes in their normal manner in their own environment and to cut and collect a minimum of 15 part-filters from only the spent cigarettes they had been provided with using their filter cutter.

On day 12 of the study, the subjects returned to the test location for visit three bringing with them their filter cutters containing cut spent part filters from the cigarettes provided at visit two (smoked over days 10 and 11 of the study). The filter cutters containing the spent filter tips were stored at ambient temperature in Romania for up to six weeks before being returned to our laboratory in two shipments where the spent part filters were stored in the filter cutters at approximately $4{ }^{\circ} \mathrm{C}$ for a maximum of ten weeks before analysis. The subjects who completed all aspects of the study were paid a stipend of 60 RON (appr. 15,-€).

Machine smoking was conducted for all the study products at regimes ISO (9-13) (puff volume $35 \mathrm{~mL}$, one puff every $60 \mathrm{~s}$ and vents open), Massachusetts (14) (puff volume $45 \mathrm{~mL}$, one puff every $30 \mathrm{~s}$ and vents half blocked) and Health Canada Intense (15) (puff volume $55 \mathrm{~mL}$, one puff every $30 \mathrm{~s}$ and vents blocked). All regimes required the cigarettes to be smoked up to $3 \mathrm{~mm}$ of the over tipping and all had puff durations of $2 \mathrm{~s}$. The smoking was conducted at standard conditions (9) of $22 \pm 2{ }^{\circ} \mathrm{C}$ and relative humidity $60 \pm 5 \%$ using SM450 linear smoking machines manufactured by Cerulean. The physical properties of each product were also measured and the tobacco blends were analysed for nicotine and sugars.

\section{Filter analysis}

The filter analysis methodology used to estimate smokers MLE has been described previously (3). In summary, the estimation of smoke yields obtained by a smoker relies on the relationship between the amount of 'tar' and nicotine delivered to the smoker and the amount retained within the filter of their cigarette as defined by calibration smoking. The subjects' spent filters collected in the filter cutters were split randomly into three groups of five tips which were analysed independently on different days. The length of each filter tip in the groups of five was measured $( \pm 0.1 \mathrm{~mm})$ and recorded before being extracted in $20 \mathrm{~mL}$ methanol containing $n$-heptadecane as an internal standard. The extracts were then analysed for both tip nicotine using gas chromatography (GC) and UV absorbance, used to determine tip 'tar', using a variable wavelength detector set at $310 \mathrm{~nm}(3)$.

To enable the estimation of MLE, calibrations were produced by machine smoking each product over a series of smoking regimes covering a wide range of typical human smoking behaviour parameters (puff volumes of $40 \mathrm{~mL}, 50 \mathrm{~mL}$ and $70 \mathrm{~mL}$, durations of $1.5 \mathrm{~s}$ and $2.0 \mathrm{~s}$ and mean flows of $20 \mathrm{~mL} / \mathrm{s}, 33 \mathrm{~mL} / \mathrm{s}$ and $47 \mathrm{~mL} / \mathrm{s}$ ). It is known that there is a gradual loss of nicotine and other smoke components from the spent filters so it is important that the conditions and length of storage time of the spent filters from calibration smoking and the smokers is similar. To achieve this, the first calibration smoking replicate of each regime was conducted at the beginning of the fieldwork and stored in aluminium cans at ambient temperature until the first shipment of human filter tips were returned from Romania. Both calibration and human generated part filters were then stored at approximately $4{ }^{\circ} \mathrm{C}$. The second replicate of each calibration smoking regime was smoked after the fieldwork had been completed and stored at ambient temperature for a week. This resulted in different storage times for the first and second calibration regime replicates. The part filters generated by calibration smoking were then analysed alongside the smokers' spent filters.

MLE to nicotine were obtained for the smokers of each product using the measured human tip nicotine values and the linear regression equation obtained by plotting 


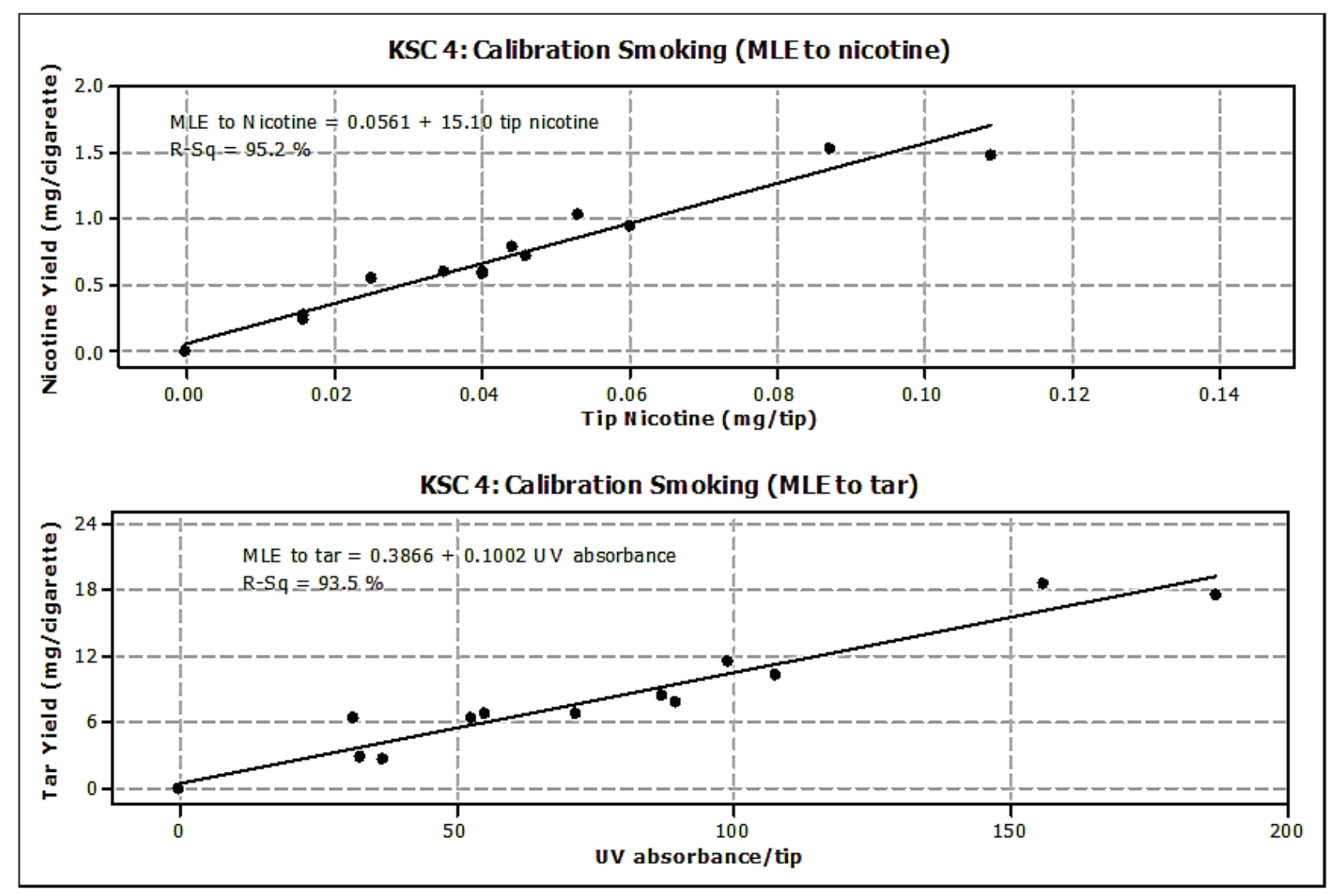

Figure 1. Calibration curves to estimate MLE to nicotine and 'tar' for KSC 4.

mainstream smoke nicotine yield versus tip nicotine data obtained during calibration smoking.

Similarly, MLE to 'tar' were obtained using UV absorbance per tip data and the linear regression equation derived by plotting mainstream smoke nicotine free dry particulate matter (NFDPM)/('tar') yield versus UV absorbance per tip during calibration. The calibration curves and associated linear regression equations used to estimate MLE to nicotine and 'tar' for KSC 4 are shown in Figure 1.

\section{Data analysis}

In this report MLE data are presented as mean \pm standard deviation (SD) and cigarette physical measurement and ISO and intense machine smoking data are presented as mean. In all cases General Linear Model (ANOVA GLM) was used to compare smokers' MLE to 'tar' and nicotine with reference to the objectives of the study, and where a significant difference was found TUKEY'S post-hoc test was carried out to determine the source of the difference. In this study the output is presented as the TUKEY's ranking and the same letter denotes no statistical difference $(p>0.05)$. Comparisons were conducted as follows:

- Smokers' MLE to 'tar' and nicotine were compared across all products.

- The effect of cigarette circumference was tested by comparing MLE to 'tar' and nicotine obtained by KSSS smokers with that obtained by KSC smokers;
Pack 'tar' nested within circumference.

- The effect of filter charcoal was tested by comparing MLE to 'tar' and nicotine obtained by KSC smokers with that obtained by KSNC smokers; Filter type (charcoal vs non-charcoal) nested within pack 'tar'.

- The effect of gender was tested by comparing MLE to 'tar' and nicotine obtained by male smokers with that obtained by female smokers; Gender nested within product.

\section{RESULTS}

Physical Measurements and ISO and Intense Machine Smoking

Table 3 contains a summary of the physical measurements and filter details for the study cigarettes.

The different cigarette types have some key differences. For example the KSSS products have a smaller circumference than the other study products which also results in them having approximately $35 \%$ to $50 \%$ less tobacco compared with the KSC and KSNC products. The filter types also differ with the KSC, KSSS and KSNC products having three, two and one filter sections respectively, and as discussed before, the length of the mouth end sections are between $7.0 \mathrm{~mm}$ and $27.2 \mathrm{~mm}$. Also, because the cigarettes have been designed to produce specified yields of 'tar' and nicotine when smoked on a 
Table 3. Pack and physical measurements.

\begin{tabular}{|c|c|c|c|c|c|c|c|c|}
\hline & KSC 1 & KSSS 1 & KSC 4 & KSSS 4 & KSNC 4 & KSC 7 & KSSS 7 & KSNC 7 \\
\hline Pack 'tar' (mg/cig) & 1 & 1 & 4 & 4 & 4 & 7 & 7 & 7 \\
\hline $\begin{array}{l}\text { Tobacco blend } \\
\text { nicotine DWB \% }\end{array}$ & 2.70 & 2.34 & 2.14 & 2.35 & 1.96 & 2.16 & 2.36 & 1.93 \\
\hline $\begin{array}{l}\text { Carbon loading in filter } \\
(\mathrm{mg})\end{array}$ & 46 & 16 & 56 & 16 & no & 40 & 16 & no \\
\hline Filter type & triple & dual & triple & dual & single & dual & dual & single \\
\hline Mouth section $(\mathrm{mm})^{\mathrm{b}}$ & 7.2 & 11 & 7 & 11 & 27.2 & 15 & 11 & 27 \\
\hline Tobacco weight (mg) & 496.3 & 316.3 & 568.7 & 314.7 & 638.4 & 624.7 & 322.3 & 634.8 \\
\hline $\begin{array}{l}\text { Cigarette PD-open } \\
\text { mm WG }^{\mathrm{c}}\end{array}$ & 96.8 & 82.4 & 89.3 & 127 & 95.2 & 82.3 & 189.3 & 93.5 \\
\hline
\end{tabular}

a Tobacco blend total alkaloids: blend nicotine, DWB: dry weight basis,

All cigarettes manufactured in BAT Ploiesti factory during standard manufacture

All pack size $=20$, length $=83 \mathrm{~mm} \pm 1 \mathrm{~mm}$, filter length $=27 \mathrm{~mm} \pm 2 \mathrm{~mm}$,

${ }^{\mathrm{b}}$ Mouth section defined for dual and triple filter types as specific filter part on mouth end and for single filters mouth end is defined as the whole filter

${ }^{c}$ PD: pressure drop, $\mathrm{mm}$ WG: $\mathrm{mm}$ water gauge

Circumference of all KSC and KSNC $=24.7 \mathrm{~mm} \pm 0.1 \mathrm{~mm}$

Circumference of all KSSS $=17.0 \mathrm{~mm} \pm 0.1 \mathrm{~mm}$

machine at the ISO regime there are design differences between the same cigarette types such as ventilation which increases at lower ISO pack 'tar'.

ISO and intense regulatory machine smoking data are presented in Table 4 . The study objective included the assumption that the study products would be matched at ISO, and the results of the ISO smoking confirmed that the $4 \mathrm{mg}$ and $7 \mathrm{mg}$ ISO 'tar' products were close to the pack values (Table 1). However, the $1 \mathrm{mg}$ ISO products were less well matched with their pack yields and the KSC 1 product obtained $0.5 \mathrm{mg} / \mathrm{cig}$ 'tar' and $0.05 \mathrm{mg} / \mathrm{cig}$ nicotine compared with the KSSS 1 product which obtained $1.6 \mathrm{mg} / \mathrm{cig}$ 'tar' and $0.15 \mathrm{mg} / \mathrm{cig}$ nicotine. Also, the KSSS products tended to yield $40 \%$ to $48 \%$ less carbon monoxide (CO) compared with the KSC and KSNC products of similar yielding ISO 'tar'. The study products tended to maintain ISO ranking for yields of 'tar' and nicotine with the $1 \mathrm{mg}$ products $<4 \mathrm{mg}$ products $<7 \mathrm{mg}$ products, but at the Health Canada intense regime there was less differentiation between ISO 'tar' bands due to ventilation blocking removing the ability of tip ventilation to modify yield.

\section{Calibration and regression equations}

The calibration slopes and intercepts used to estimate MLE to 'tar' and nicotine in this study are included in Table 5. The differences between the slopes are due in part to different cigarette design characteristics. For example the KSSS products have low filter efficiencies (FE) because their smaller circumference results in less surface area in the filter and a high flow rate through the filter which reduces the filters ability to trap the particulate matter from the mainstream smoke compared with the other study products. Another design feature leading to slope differences were the short mouth end sections of the $\mathrm{KSC}$ products $(7 \mathrm{~mm})$ which were cut to $5 \mathrm{~mm}$ to prevent the inclusion of carbon in the part filter resulting in less material in filter tip compared with the mainstream smoke. The different storage times of the first and second replicate part filters generated by calibration smoking as discussed before could potentially result in a small loss of nicotine and 'tar' from those part filters stored longest at ambient temperature. The 'tar' yield, nicotine yield, part

Table 4. ISO and intense machine smoking.

\begin{tabular}{ll|c|c|c|c|c|c|c|c}
\hline Regime & & KSC 1 & KSSS 1 & KSC 4 & KSSS 4 & KSNC 4 & KSC 7 & KSSS 7 & KSNC 7 \\
\hline \multirow{2}{*}{ ISO } & 'Tar' (mg/cig) & 0.5 & 1.6 & 4.0 & 4.1 & 4.7 & 7.6 & 7.5 & 7.2 \\
35/2/60 & Nicotine (mg/cig) & 0.05 & 0.15 & 0.35 & 0.38 & 0.35 & 0.63 & 0.66 & 0.50 \\
vb 0\% & CO (mg/cig) & 0.9 & 0.8 & 5.1 & 3.2 & 5.2 & 7.5 & 5.8 & 7.7 \\
& Puffs per Cig & 7.0 & 6.6 & 6.8 & 6.0 & 8.0 & 7.2 & 5.8 & 7.0 \\
Massachusetts & 'Tar' (mg/cig) & 6.6 & 6.8 & 13.3 & 11.8 & 12.8 & 19.6 & 15.3 & 17.8 \\
45/2/30 & Nicotine (mg/cig) & 0.65 & 0.69 & 1.09 & 1.12 & 1.07 & 1.61 & 1.36 & 1.32 \\
vb 50\% & CO (mg/cig) & 9.5 & 4.9 & 15.9 & 9.2 & 14.7 & 17.7 & 11.1 & 18.5 \\
& Puffs per Cig & 9.9 & 10.8 & 9.2 & 9.1 & 11.3 & 10.7 & 8.3 & 10.5 \\
Health Canada & 'Tar' (mg/cig) & 17.5 & 19.4 & 21.7 & 19.8 & 21.9 & 27.5 & 20.4 & 23.6 \\
Intense & Nicotine (mg/cig) & 1.32 & 1.53 & 1.52 & 1.55 & 1.51 & 2.04 & 1.61 & 1.58 \\
55/2/30 & CO (mg/cig) & 22.0 & 13.5 & 24.2 & 13.4 & 24.3 & 24.8 & 13.4 & 23.3 \\
vb 100\% & Puffs per Cig & 6.5 & 7.4 & 7.2 & 7.9 & 9.3 & 9.1 & 7.5 & 8.8 \\
\hline
\end{tabular}

vb: ventilation blocking 
Table 5. Summary of slopes and intercepts of the calibration curves.

\begin{tabular}{|c|c|c|c|c|c|c|c|c|c|c|}
\hline \multirow{3}{*}{ Product } & \multirow{3}{*}{$\begin{array}{l}\text { Pack } \\
\text { 'tar' } \\
(\mathrm{mg})\end{array}$} & \multicolumn{6}{|c|}{ Nicotine yield versus tip nicotine } & \multirow{2}{*}{\multicolumn{3}{|c|}{$\begin{array}{c}\text { 'Tar' yield versus tip UV } \\
\text { absorbance }\end{array}$}} \\
\hline & & \multicolumn{3}{|c|}{ Lab B } & \multicolumn{3}{|c|}{ Lab A } & & & \\
\hline & & Slope & Int & $R^{2} \%$ & Slope & Int & $\mathrm{R}^{2} \%$ & Slope & Int & $\mathrm{R}^{2} \%$ \\
\hline KS SS 1 & 1 & 6.469 & -0.006 & 98.9 & 7.539 & 0.029 & 95.1 & 0.057 & -0.305 & 98.7 \\
\hline KSC 1 & 1 & 9.396 & -0.044 & 99.3 & 9.368 & -0.04 & 88.2 & 0.058 & -0.326 & 91.3 \\
\hline KS SS 4 & & 10.04 & 0.008 & 98.8 & 11.498 & 0.034 & 97.6 & 0.084 & -0.273 & 96.6 \\
\hline KSC 4 & 4 & 15.380 & 0.03 & 99.2 & 15.104 & 0.056 & 95.2 & 0.100 & 0.387 & 93.5 \\
\hline KSNC 4 & & 4.24 & -0.019 & 98.5 & 4.706 & -0.013 & 96.4 & 0.033 & -0.471 & 91 \\
\hline KS SS 7 & & 10.580 & 0.0388 & 99.7 & 12.533 & 0.052 & 96.8 & 0.102 & -0.633 & 97.3 \\
\hline KSC 7 & 7 & na & na & na & 8.043 & 0.062 & 97.6 & 0.061 & -0.275 & 96.6 \\
\hline KSNC 7 & & 5.17 & -0.022 & 99.7 & 5.563 & 0.04 & 96.8 & 0.043 & -0.451 & 93.9 \\
\hline
\end{tabular}

Int: intercept

filter nicotine and UV absorbance per tip replicate data were compared using two-sample t-tests and no differences were found, $p=0.693,0.830,0.566$ and 0.544 respectively. To further verify robustness of the calibration smoking data, another laboratory (Lab B) conducted calibration smoking using the same products. Only enough cigarettes were available to conduct one replicate for seven of the eight products, but the slopes and intercepts obtained by Lab B for pad nicotine versus tip nicotine were in agreement with our laboratory (Lab A) and are included in Table 5 . The $\mathrm{R}^{2}$ values obtained by our laboratory were slightly lower than those obtained by Lab B due to the small differences between independent replicates conducted for each smoking regime, and this was supported by the $\mathrm{R}^{2}$ values obtained for our first replicate which ranged from $98.0 \%$ to $99.8 \%$. Pad NFDPM versus tip UV absorbance equations obtained by lab B were not included because different instruments can give different absolute results in integrated absorbance units (3) and therefore cannot be directly compared with those generated by our laboratory (Lab A).

\section{Smoker mouth level exposure}

The mean, SD, minimum (min) and maximum (max) values are listed in Table 6. For all products assessed, the mean MLE to 'tar' and nicotine obtained by the smokers of each product on a per cigarette basis were greater than the 'tar' and nicotine yields obtained by machine smoking at ISO as would be expected and the variation in smoking behaviour resulted in a range of MLE to 'tar' and nicotine for the smokers.

The MLE to 'tar' and nicotine obtained by the smokers of each product were compared using ANOVA GLM, and the TUKEY'S ranking are also included in Table 6. Regarding the smokers of products within an ISO pack 'tar', MLE to 'tar' were similar to each other. The smokers also maintained ISO ranking and the $1 \mathrm{mg}$ ISO smokers yielded significantly less than the $4 \mathrm{mg}$ ISO smokers who yielded significantly less than the $7 \mathrm{mg}$ ISO smokers $(1 \mathrm{mg}<4 \mathrm{mg}$ $<7 \mathrm{mg}$ ). For MLE to nicotine, ISO ranking tended to be maintained, but there was some overlap between the ISO 'tar' bands, and the KSNC smokers obtained significantly lower MLE to nicotine than the KSSS and KSC smokers in the same ISO 'tar' group in most cases. The PEARSON correlation coefficient between the smokers MLE to 'tar' and nicotine and the study products ISO 'tar' and nicotine were 0.728 and 0.668 respectively, $p<0.001$.

The effect of cigarette circumference (format), charcoal in the cigarette filter and gender on the smokers MLE were investigated using nested ANOVA GLM and the $p$ values obtained are listed in Table 7. Pack 'tar' was nested within format (KSSS compared with KSC) and filter type (KSC compared with KSNC) was nested within pack 'tar' and in

Table 6. Comparison of MLE obtained by the smokers across all products.

\begin{tabular}{|c|c|c|c|c|c|c|c|}
\hline \multirow[b]{2}{*}{ Product } & \multirow{2}{*}{$\begin{array}{l}\text { Pack } \\
\text { 'tar' } \\
(\mathrm{mg})\end{array}$} & \multicolumn{3}{|c|}{ MLE to 'tar' (mg/cig) } & \multicolumn{3}{|c|}{ MLE to nicotine (mg/cig) } \\
\hline & & mean $\pm S D$ & $\begin{array}{l}{ }^{*} \text { TUKEY'S } \\
\text { rankinga }\end{array}$ & $\min -\max$ & mean $\pm S D$ & $\begin{array}{l}{ }^{*} \text { TUKEY'S } \\
\text { ranking }\end{array}$ & $\min -\max$ \\
\hline $\begin{array}{l}\text { KSC } 1 \\
\text { KSSS } 1\end{array}$ & 1 & $\begin{array}{l}5.7 \pm 2.2 \\
7.1 \pm 2.1\end{array}$ & $\begin{array}{l}a \\
a\end{array}$ & $\begin{array}{l}1.6-12.6 \\
3.1-11.4\end{array}$ & $\begin{array}{l}0.64 \pm 0.25 \\
0.70 \pm 0.19\end{array}$ & $\begin{array}{c}a \\
a b\end{array}$ & $\begin{array}{l}0.13-1.28 \\
0.28-1.13\end{array}$ \\
\hline $\begin{array}{l}\text { KSNC } 4 \\
\text { KSC } 4 \\
\text { KSSS } 4\end{array}$ & 4 & $\begin{array}{l}11.0 \pm 3.1 \\
11.9 \pm 2.9 \\
10.5 \pm 2.2\end{array}$ & $\begin{array}{l}b \\
b \\
b\end{array}$ & $\begin{array}{l}3.4-16.9 \\
5.5-19.0 \\
6.5-16.6\end{array}$ & $\begin{array}{l}0.86 \pm 0.24 \\
1.04 \pm 0.28 \\
1.00 \pm 0.20\end{array}$ & $\begin{array}{r}\mathrm{bc} \\
\mathrm{d} \\
\mathrm{cd}\end{array}$ & $\begin{array}{l}0.33-1.38 \\
0.47-1.73 \\
0.60-1.59\end{array}$ \\
\hline $\begin{array}{l}\text { KSNC } 7 \\
\text { KSC } 7 \\
\text { KSSS } 7\end{array}$ & 7 & $\begin{array}{l}14.9 \pm 4.7 \\
16.3 \pm 4.2 \\
15.2 \pm 3.7\end{array}$ & $\begin{array}{l}\mathrm{C} \\
\mathrm{C} \\
\mathrm{C}\end{array}$ & $\begin{array}{l}6.7-25.0 \\
7.1-28.7 \\
7.8-25.3\end{array}$ & $\begin{array}{l}1.08 \pm 0.34 \\
1.40 \pm 0.33 \\
1.36 \pm 0.33\end{array}$ & $\begin{array}{l}d \\
e \\
e\end{array}$ & $\begin{array}{l}0.53-1.76 \\
0.62-2.46 \\
0.65-2.13\end{array}$ \\
\hline
\end{tabular}

${ }^{\text {a }}$ Same letter indicates no statistical difference: $p>0.05$ 
Table 7. Effect of format, charcoal and gender on MLE to 'tar' and nicotine.

\begin{tabular}{l|c|c|c}
\hline \multirow{2}{*}{ Comparison } & \multirow{2}{*}{ Products } & \multicolumn{2}{|c}{$\mathrm{p}$ value } \\
\cline { 3 - 4 } & & $\begin{array}{c}\text { MLE to } \\
\text { 'tar' }\end{array}$ & $\begin{array}{c}\text { MLE to } \\
\text { nicotine }\end{array}$ \\
\hline $\begin{array}{c}\text { Format } \\
\text { KSC vs KSSS }\end{array}$ & charcoal & 0.251 & 0.793 \\
$\begin{array}{c}\text { Charcoal } \\
\text { KSC vs KSNC }\end{array}$ & 4 and $7 \mathrm{mg}$ & 0.049 & $<0.001$ \\
Gender & all & 0.414 & 0.328 \\
\hline
\end{tabular}

both cases the effect of pack 'tar' was significant $(p<0.001)$.

There was no evidence that circumference influenced MLE, and this is illustrated for both the MLE to 'tar' and nicotine obtained by the smokers using box whisker plots in Figures 2 and 3 respectively. The smokers of products within an ISO pack 'tar' yielded similar MLE. They also maintained ISO ranking and $1 \mathrm{mg}<4 \mathrm{mg}<7 \mathrm{mg}$.

MLE to 'tar' and nicotine obtained for the smokers of KSC and KSNC products to test the effect of filter charcoal are illustrated in Figures 4 and 5 respectively using box whisker plots. Regarding MLE to 'tar', no differences were found within ISO pack 'tar', but the smokers of the $4 \mathrm{mg}$ ISO products yielded significantly less than the smokers of $7 \mathrm{mg}$ ISO products. For MLE to nicotine, the smokers of the KSNC product yielded significantly less than the smokers of the KSC product at both $4 \mathrm{mg}$ and $7 \mathrm{mg}$ ISO 'tar'. Regarding gender, there was no evidence that it influenced MLE.

\section{DISCUSSION}

The aims of this study were to use filter analysis methodology to evaluate whether cigarette circumference or charcoal in the filter have any influence on the MLE to 'tar' and nicotine obtained by smokers. We found no evidence that the reduced circumference of the KSSS cigarettes changed smokers' MLE to 'tar' and nicotine compared with the other study products and this can partly be explained by their design characteristics. The small circumference of the KSSS filter results in a high flow rate through the filter and this combined with a reduced filter surface area means less of the particulate matter is removed from the mainstream smoke. So less tobacco is burnt per puff, but more of the mainstream smoke passes through the filter compared with the other study products. The filter has no impact on $\mathrm{CO}$ and so it is likely that the KSSS products will have less CO relative to 'tar' in the mainstream smoke. This is supported by the ISO and intense regulatory machine smoking which provided evidence that the KSSS products yielded $40 \%$ to $48 \%$ less CO compared with similar ISO 'tar' band products in the study. However, measures of CO intake were not in the scope of this study. Evidence that design changes do not necessarily change smokers' MLE to 'tar' and nicotine was provided by CôTÉ et al. (6) who showed that the design changes for low ignition propensity (LIP) cigarettes did not influence smokers' MLE to 'tar' and nicotine.
We found no evidence that activated carbon in the filter influences smokers MLE to 'tar' and nicotine and this should be expected because carbon is used primarily to reduce vapour phase species (16) and nicotine is $100 \%$ particle bound in mainstream smoke. The tendency for the smokers of the KSNC products to obtain less MLE to nicotine compared with smokers of other study products with the same ISO pack 'tar', is likely to be due to the KSNC products containing less nicotine in the tobacco blend ( 1.96 and $1.93 \%$ dry weight) compared with the other study products ( 2.14 to $2.70 \%$ dry weight). The KSNC 7 also had lower pack nicotine and obtained a lower ISO nicotine yield compared with the other $7 \mathrm{mg}$ pack 'tar' products.

In this study, comparison of average MLE to 'tar' and nicotine on a per cigarette basis found that the $1 \mathrm{mg}$ smokers $<4 \mathrm{mg}$ smokers $<7 \mathrm{mg}$ smokers with the exception of the KSNC smokers who in most cases obtained significantly less MLE to nicotine compared with the smokers of the other products with the same ISO pack 'tar'. In general, ambulatory population studies with multiple cigarette brands show only weak correlations between ISO 'tar' and nicotine yields and smokers' exposure to nicotine or other smoke constituents (17) or no significant trends (18). In contrast, previous studies have found a correlation between the ISO nicotine yields and smokers' exposure to nicotine - clinical studies $(7,19)$ and ambulatory studies $(1$, $4,6)$. The lower correlation between ISO nicotine yields and smokers' exposure to nicotine found in biomarker studies compared with MLE studies is likely to be due to smoker variability in MLE to nicotine combined with the additional subject variability in nicotine retention and metabolism (1); also in ambulatory studies non-compliance to the protocol could add further uncertainty to the results. SHEPPERD et al. (7) and MENDES et al. (19) used a clinical environment thus controlling the cigarette type smoked by the subjects, recording the subjects' cigarette consumption and ensuring complete urine collection. In our study, we targeted smokers of products with specific ISO 'tar' levels with a gap of $3 \mathrm{mg}$ ISO 'tar' between each level. SHEPPERD et al. (7) discussed that the division of smokers into groups based on 'tar' bands rather than specific 'tar' yield could make it impossible to distinguish between the groups, and that some kind of separation is needed to improve the chance of finding a difference between smoker groups if indeed one exists.

We found that smokers' MLE to 'tar' and nicotine varied widely even within a given ISO pack 'tar' band so ISO yield cannot be used as a predictor of individual smoker 'tar' and nicotine yields which is in agreement with other studies $(1,4,6,7,17)$. The smokers mean MLE to 'tar' and nicotine were best aligned with the Massachusetts smoking regime, and we found in agreement with previous studies $(1,6)$ that the ISO smoking regime underestimated most of the smokers' yields ( $>99.99 \%$ in our study) while the Health Canada Intense smoking regime overestimated most of the smokers' yields ( $>99.95 \%$ in our study).

The mean MLE to 'tar' (5.7 and $7.1 \mathrm{mg}$ per cigarette) and nicotine ( 0.64 and $0.70 \mathrm{mg}$ per cigarette) obtained by the smokers of the $1 \mathrm{mg}$ ISO pack 'tar' products in this study compared favourably with previous studies where direct comparison was possible. CÔTÉ et al. (6), MARINER et al. 


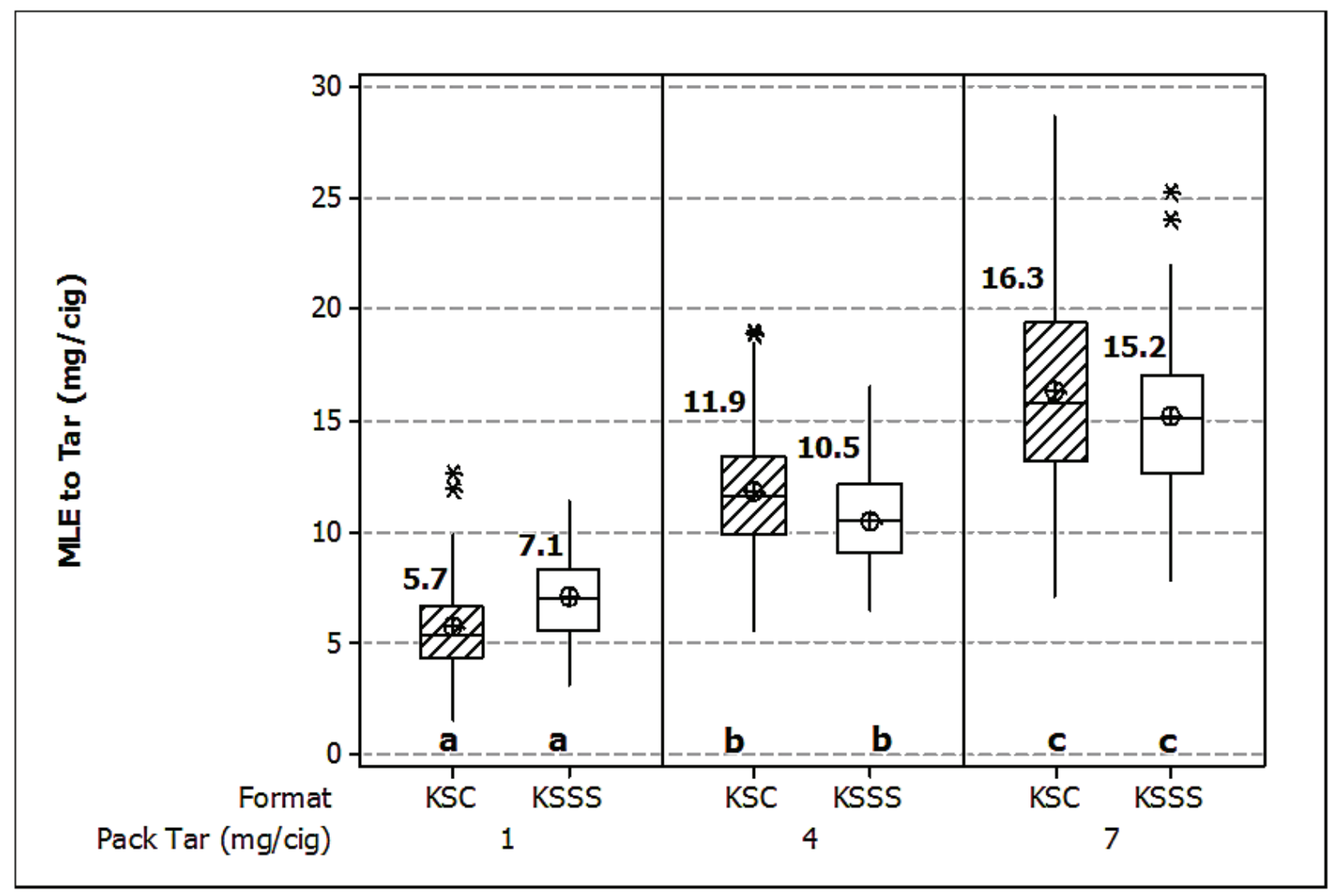

Figure 2. The effect of circumference on MLE to 'tar' (KSC versus KSSS). TUKEY's posthoc test; same letter indicates no statistical difference: $p>0.05$

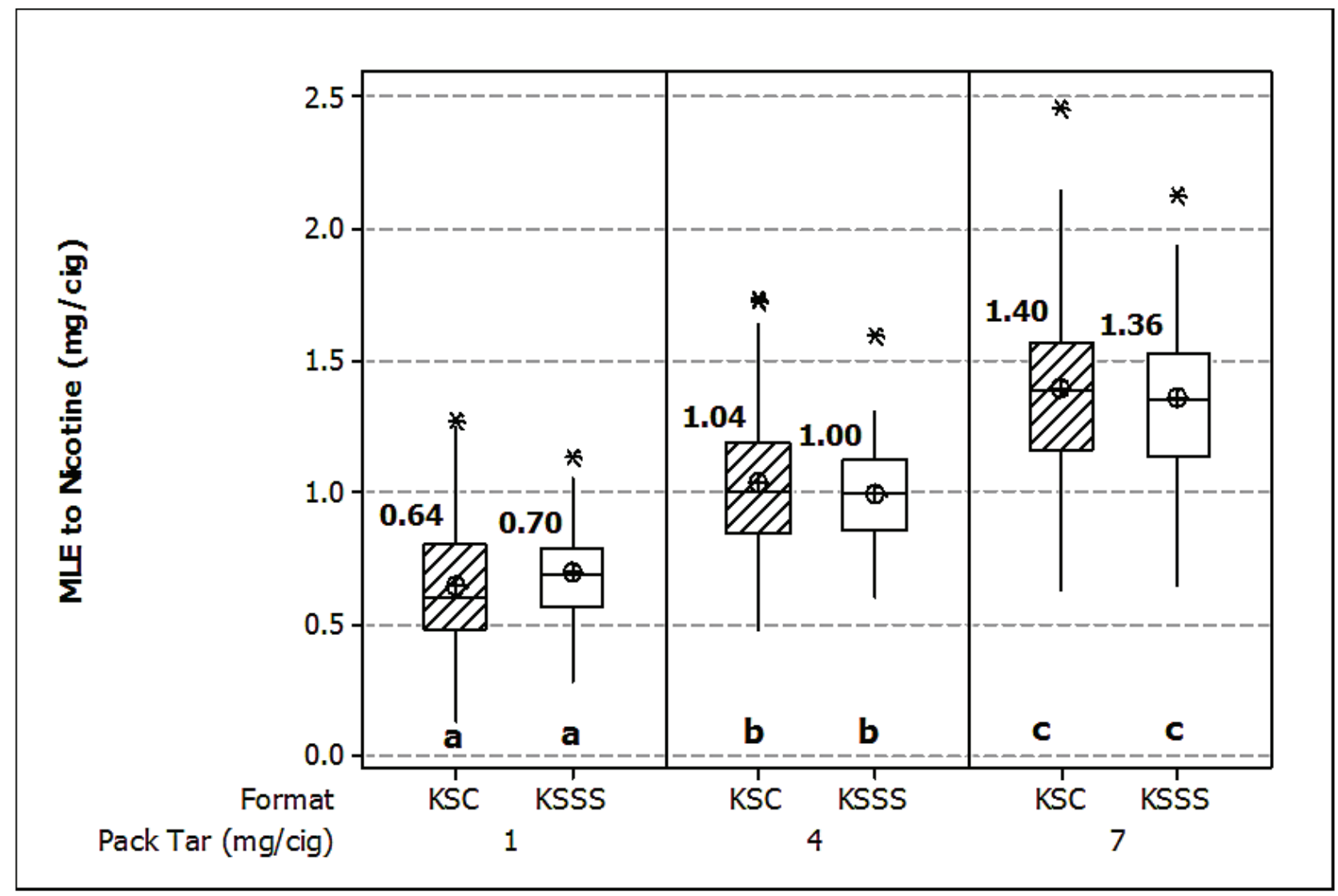

Figure 3. The effect of circumference on MLE to nicotine (KSC versus KSSS). TUKEY's posthoc test; same letter indicates no statistical difference: $p>0.05$ 


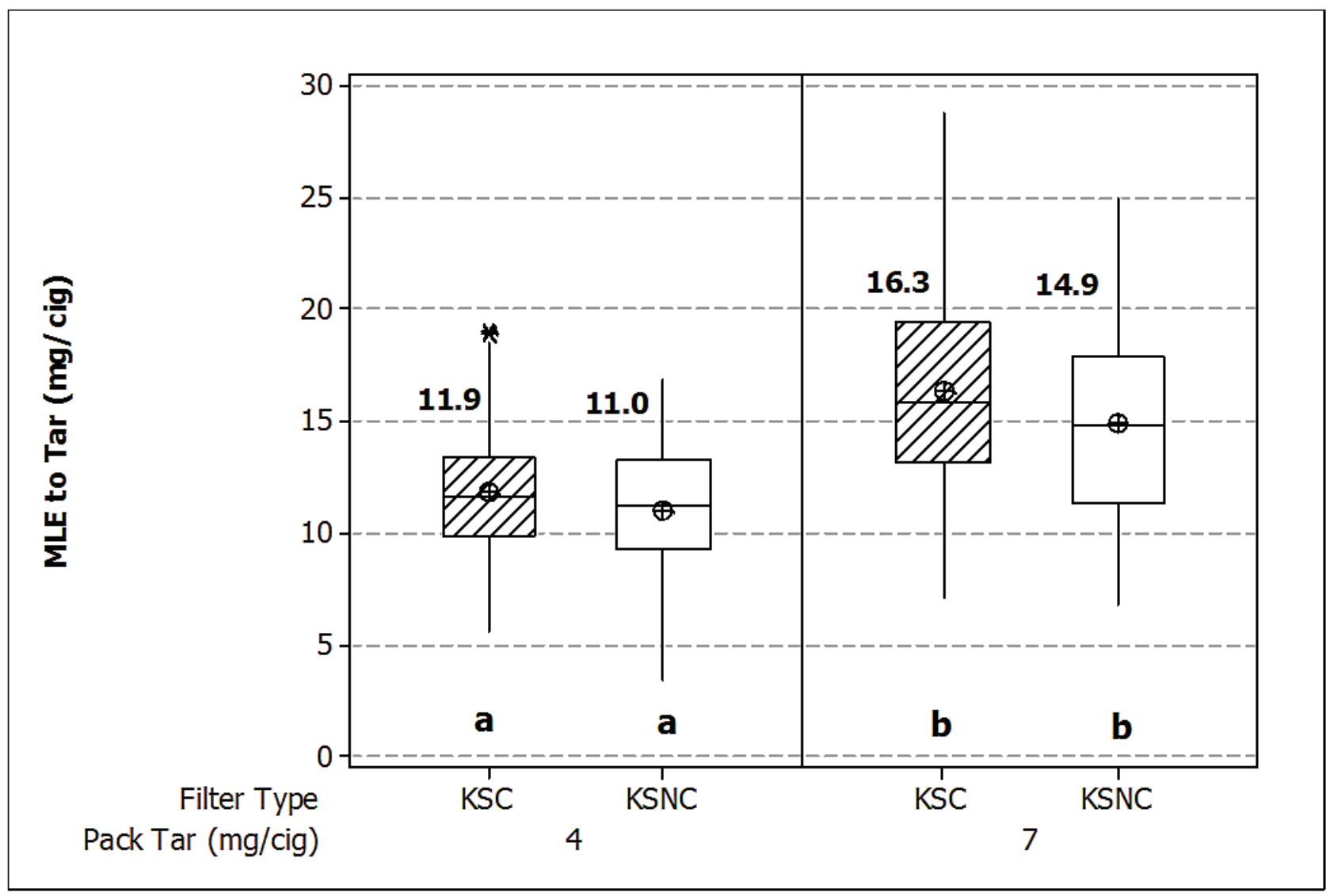

Figure 4. The effect of charcoal in the filter on MLE to 'tar' (KSC versus KSNC). TUKEY's posthoc test; same letter indicates no statistical difference: $p>0.05$

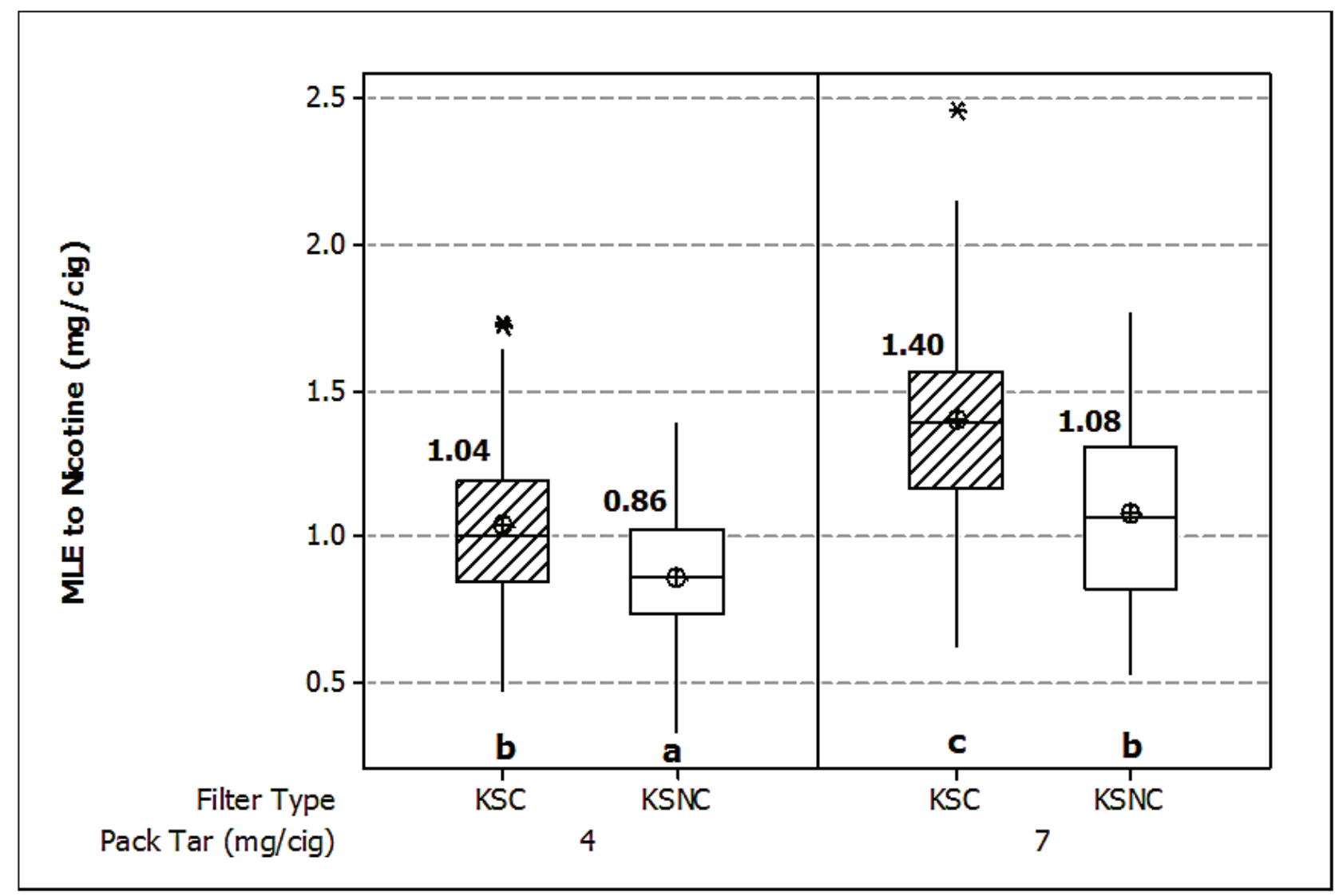

Figure 5. The effect of charcoal in the filter on MLE to nicotine (KSC versus KSNC). TUKEY's posthoc test; same letter indicates no statistical difference: $p>0.05$ 
(4) and ST CHARLES et al. (1) reported MLE to 'tar' ranging from 5.0 to $7.8 \mathrm{mg}$ per cigarette and MLE to nicotine ranging from 0.41 to $0.77 \mathrm{mg}$ per cigarette. The mean MLE to 'tar' $(11.0,11.9$ and $10.5 \mathrm{mg}$ per cigarette) and nicotine (0.86, 1.04 and $1.00 \mathrm{mg}$ per cigarette) obtained by the smokers of the $4 \mathrm{mg}$ ISO pack 'tar' products in our study are also comparable with CôTÉ et al. (6) who obtained 10.4 and $9.9 \mathrm{mg}$ per cigarette for 'tar' and 1.08 and $1.01 \mathrm{mg}$ per cigarette for nicotine for smokers of products with similar ISO 'tar'. ST CHARLES et al. (1) obtained similar MLE to 'tar' (9.2 mg per cigarette), but the MLE to nicotine tended to be lower probably due to more mainstream smoke 'tar' compared with smoke nicotine $(\mathrm{T} / \mathrm{N})$ of their study cigarettes compared with the $\mathrm{T} / \mathrm{N}$ of our study cigarettes; supported by the FTC (20) and ISO smoking. The mean MLE to 'tar' and nicotine obtained by the smokers of the $7 \mathrm{mg}$ ISO pack 'tar' products in our study tend to be higher, particularly for MLE to 'tar', than those obtained by CôTÉ et al. (6) for smokers of similar ISO 'tar' products. The exact reason is unknown, but may be a combination of different products and different smoker groups.

Previous studies $(4,6)$ have found that in some countries males tend to obtain higher MLE to 'tar' and nicotine than females thus smoker groups of varying demographics could influence the results. The smokers of KSSS cigarettes in Romania tend to be females so to mitigate the possible effect of gender we recruited an approximately equal number of male and female smokers, but comparison of MLE by gender found no difference (Table 7).

ST CHARLES et al. (3) describe the part filter methodology used in our study and mainly refer to filters cut to $10 \mathrm{~mm}$, but they point out that where mouth end sections are less than $10 \mathrm{~mm}$ it is possible to cut to $7 \mathrm{~mm}$. The KSC products in this study have triple filters with carbon in the middle and a $7 \mathrm{~mm}$ mouth end segment and it was necessary to cut $5 \mathrm{~mm}$ portions from the mouth end for analysis. PAULY et al. (2) discuss that the filter is a target of innovation resulting in more products having complex filters. Many of these filters contain carbon as did the KSC and KSSS cigarettes in our study and contrary to what is suggested (2), part filter analysis methodology enables MLE to be assessed for smokers of carbon products providing the portion of filter is cut to a length short enough to prevent the inclusion of carbon particles. Previous unpublished work conducted by CôTÉ et al. has shown that MLE to 'tar' and nicotine (range 1.3 and $26.8 \mathrm{mg} / \mathrm{cig}$ and 0.13 and $2.44 \mathrm{mg} / \mathrm{cig}$ respectively) derived using filters cut to $5 \mathrm{~mm}$ are as accurate $( \pm 10 \%)$ and as precise $(<10 \%$ variation) as those generated from $10 \mathrm{~mm}$ mouth end portions. ST CHARLES et al. (3) also explain that for accurate estimation of MLE, calibration smoking regimes should comprise flow rates that cover those expected for human smoked cigarettes because filtration efficiency (FE) or the amount of smoke particulates trapped by the cigarette filter relative to what passes through the filter increases as flow rate decreases. If regimes with flow rates lower than those typically generated by smokers are used such as ISO, Massachusetts or Health Canada Intense the FE of the machine smoked filters is likely to be higher than the FE of the smokers' filters and this could cause the smokers MLE to be underestimated.

St CHARLES (3) also points out that extreme care must be taken when assessing products with FE of the part filter less than $10 \%$ (i.e. products in this study where the slope for nicotine yield versus tip nicotine is greater than ten) because small measurement variations of the smokers spent filters will result in large differences in the estimation of their MLE and he suggests that additional replicates be added to the calibration smoking. No additional replicates were added, but as discussed before, another laboratory conducted calibration smoking and obtained similar calibration equations. The publication (3) also discussed the stability of the human filter tips regarding 'tar' and nicotine and referenced data that showed no significant losses occurred over four weeks at $22{ }^{\circ} \mathrm{C}$ and over 12 months at $4{ }^{\circ} \mathrm{C}$. Due to the duration of the study, some of the smokers' spent filter tips were stored for longer than four weeks at ambient temperature and it is possible that there were small losses of 'tar' and nicotine from some of the filters which could potentially result in underestimating the MLE. However, the randomised collection of the spent filters from smokers of different cigarettes and the similar aging of the calibration filter tips should mediate any loss of material from the smokers' spent filters. Furthermore, comparison of the tip nicotine content and UV absorbance of calibration filter tips stored for six weeks at ambient temperature with those stored for a week at ambient temperature showed no difference, $p>0.05$.

However, it is recommended that for future studies conducted over a period of time, additional calibration smoking replicates should be added spaced throughout the duration of the study. It is also recommended that filter tips are stored at $4{ }^{\circ} \mathrm{C}$ as soon after collection as possible.

\section{CONCLUSIONS}

No significant difference was found between the MLE to 'tar' and nicotine obtained by smokers of the KSSS (17.0 mm circumference) and KSC (24.7 mm circumference) products at $1 \mathrm{mg}, 4 \mathrm{mg}$ and $7 \mathrm{mg}$ ISO pack 'tar' providing no evidence that cigarette circumference had any influence.

No significant difference was found between the MLE to 'tar' obtained by smokers of KSC (charcoal filter) and smokers of KSNC (cellulose acetate filter) at $4 \mathrm{mg}$ and $7 \mathrm{mg}$ ISO pack 'tar' providing no evidence that charcoal in the filter had any influence. However, MLE to nicotine for the KSNC smokers was significantly less than that of the KSC smokers at both $4 \mathrm{mg}$ and $7 \mathrm{mg}$ ISO pack 'tar', which corresponded to a lower blend nicotine content of the KSNC studied.

Comparison of MLE to 'tar' obtained by smokers across all products found no significant differences within an ISO pack 'tar' and products maintained ISO pack 'tar' ranking with the $1 \mathrm{mg}$ products $<4 \mathrm{mg}$ products $<7 \mathrm{mg}$ products, averaged over the study population.

Regarding MLE to nicotine, ISO pack 'tar' ranking tended to be maintained with the exception of the KSNC smokers who in most cases obtained significantly less MLE to nicotine compared with the smokers of the other products with the same ISO pack 'tar'. 


\section{REFERENCES}

1. St Charles, F.K., A.A. Kabbani, and M.F. Borgerding: Estimating 'tar' and nicotine exposure: Human smoking versus machine generated smoke yields; Regul. Toxicol. Pharmacol. 56 (2010) 100-110.

2. Pauly, J.L., R.J. O’Connor, G.M. Paszkiewicz, K.M. Cummings, M.V. Djordjevic, and P.G. Shields: Cigarette Filter-based Assays as Proxies for Toxicant Exposure and Smoking Behaviour - A Literature Review; J. Cancer Epidemiol. Biomarkers Prev. 18 (2009) 3321-3333.

3. St Charles, F.K., M. Ashley, C.J. Shepperd, P. Clayton and G. Errington: A Robust Method for Estimating Human Smoked Cigarette Yields from Filter Analysis Data; Beitr. Tabakforsch. Int. 23 (2009) 232-243.

4. Mariner, D.C., M. Ashley, C.J. Shepperd, G. Mullard, and M. Dixon: Mouth level smoke exposure using analysis of filters from smoked cigarettes: A study of eight countries; Regul. Toxicol. Pharmacol. In press, 2010.

5. Ashley, M., P. Saunders, G. Mullard, K. Prasad, D. Mariner, J. Williamson, and A. Richter: Smoking intensity before and after introduction of the public place smoking ban in Scotland; Regul. Toxicol. Pharmacol. In press, 2010.

6. Côté, F., C. Létourneau, G. Mullard, and R. Voisine: Estimation of nicotine and 'tar' yields from human-smoked cigarettes before and after the implementation of the cigarette ignition propensity regulations in Canada; Regul. Toxicol. Pharmacol. In press, 2010.

7. Shepperd, C.J., A.C. Eldridge, D.C. Mariner, M. McEwan, G. Errington, and M. Dixon: A study to estimate and correlate cigarette smoke exposure in smokers in Germany as determined by filter analysis and biomarkers of exposure; Regul. Toxicol. Pharmacol. 55 (2009) 97-109.

8. CORESTA recommended method No. 9 - Determination of nicotine in cigarette filters by gas chromatographic analysis (2009); available at: http://www. coresta.org/Recommended_Methods/CRM_09-update2. pdf (Accessed July 2011).

9. ISO 3308: Routine analytical cigarette smoking machine - Definition and standard conditions; International Organisation for Standardisation, Geneva, 2000.

10. ISO 4387: Cigarettes - Determination of total and nicotine free dry particulate matter using a routine analytical smoking machine; International Organisation for Standardisation, Geneva, 2000.

11. ISO 10362-1: Cigarettes - Determination of water in smoke condensates, Part 1: Gas-chromatographic method; International Organisation for Standardisation, Geneva, 1999.

12. ISO 10315: Methods for chemical analysis of tobacco and tobacco products. Determination of nicotine in smoke condensate of cigarettes (gas chromatographic method); International Organisation for Standardisation, Geneva, 1991.

13. ISO 8454: Cigarettes - Determination of carbon monoxide in the vapour phase of cigarette smoke - NDIR method; International Organisation for Standardisation, Geneva, 2007.

14. Commonwealth of Massachusetts, 1997. Tobacco disclosure act. General laws of Massachusetts, Chapter 94, Section 307B, 105 CMR 660.000. Cigarette and smokeless tobacco products: reports of added constituents and nicotine ratings.

15. Canada 2000. Tobacco reporting regulations. T-115/SOR/2000-272 ; available at: http://www.hc-sc. gc.ca/hc-ps/tobac-tabac/legislation/reg/indust/method /_main-principal/nicotine-eng.php (Accessed July 2011).

16. Branton, P. and R.H. Bradley: Activated Carbons for the Adsorption of Vapours from Cigarette Smoke; Adsorpt. Sci. Technol. 28 (2010) 3-21.

17. Scherer G., J. Engl, M. Urban, G. Gilch, D. Janket, and K. Riedel: Relationship between machine-derived smoke yields and biomarkers in cigarette smokers in Germany; Regul. Toxicol. Pharmacol. 47 (2007) 171-183.

18. Hecht S.S., S.E. Murphy, S.G. Carmella, S. Li, J. Jensen, C. Le, A.M. Joseph, and D.K. Hatsukami: Similar Uptake of Lung Carcinogens by Smokers of Regular, Light and Ultralight Cigarettes; Cancer Epidemiol. Biomarkers Prev. 14 (2005) 693-698.

19. Mendes P., S. Kapur, J. Wang, S. Feng, and H. Roethig: A randomized controlled exposure study in adult smokers of full flavour Marlboro cigarettes switching to Marlboro Lights or Marlboro Ultra Lights cigarettes; Regul. Toxicol. Pharmacol. 51 (2008) 295-305.

20. Federal Trade Commission: Cigarettes: Testing for 'tar' and nicotine content; Fed. Regist. 1967, 32, 11178.

Corresponding author:

Madeleine Ashley

British American Tobacco

Southampton SO158TL, UK

E-mail: madeleine_ashley@bat.com 